\title{
The Impact of Service Quality on Passenger Loyalty through The Mediating Roles of Relationship Quality: Evidence from Domestic Flights of Vietnamese Low-Cost Airlines
}

\author{
Ha Nam Khanh Giao a , Bui Nhat Vuong ${ }^{\mathrm{a}^{*}}$, Hasanuzzaman Tushar ${ }^{\mathrm{b}}$ \\ ${ }^{a}$ Faculty of Air Transport, Vietnam Aviation Academy, Ho Chi Minh City 700000, Vietnam
}

${ }^{b}$ College of Business Administration, International University of Business Agriculture and Technology, Dhaka 1230, Bangladesh

\begin{abstract}
The aim of this research is to investigate the effect of service quality on passenger loyalty as well as the mediating roles of relationship quality (perceives value, passenger trust, and satisfaction). The survey was conducted with a total of 321 passengers who have used low-cost airline service in the domestic terminal in Tan Son Nhat airport, Ho Chi Minh City, Vietnam; then the partial least squares structural equation modeling (PLS-SEM) was estimated using the SmartPLS 3.0 program. The results indicated that service quality positively impacted passenger loyalty. Moreover, this study provided empirical evidence about the mediating roles of perceived value, passenger trust, and satisfaction. The finding also suggested that airline managers should understand the customers' expectations and passenger loyalty regarding low-cost airlines to attract new customers as well as retain their existing customers.

(C) 2020 The Authors. Published by Elsevier B.V.

This is an open access article under the CC BY-NC-ND license (http://creativecommons.org/licenses/by-nc-nd/4.0/)

Peer-review under responsibility of the scientific committee of the 1st International Conference on Aviation Future: Challenge and Solution

Keywords: service quality; relationship quality; passenger loyalty; low-cost airline.
\end{abstract}

\section{Introduction}

Vietnam's airline market is a market with a population of 97 million, shared by 5 airlines (included Vietnam Airlines, Jetstar Pacific Airlines, VietJet Air, Bamboo Airlines) almost operating domestic and short-haul routes but Vietnam Airlines is a flag carrier of Vietnam with both domestic and international routes. In the situation of Vietnam changing from agriculture to a service market, Vietnam is opening the door to welcome foreign investments from all over the world, the standard of living higher, moreover indoor and outdoor tourist market developing... as a result, the demand for air transportation increasing significantly. It creates a potential airline market in Vietnam.

\footnotetext{
${ }^{*}$ Corresponding author. Tel.: +84908580139 .

E-mail address: nhatvuonga1@gmail.com
} 
Nevertheless, the airline industry has been continuously operating on extremely thin margins with high operational costs. Thus, the volume is crucial for the industry to stay profitable; the differences in prices for one flight can be huge. Furthermore, the actual product of the airline industry (airline seats) is extremely perishable. Once the aircraft takes off, the opportunity to sell a seat is lost. Also, Vietnam's Government control in the airfare via fare cap can cause the situation more problems. There are many difficulties that airlines face, so it is necessary to find a solution for Vietnam's airlines. The solution must solve the current problem: "How to tradeoff between the passenger's demand and airline profit to keep the business in the right way and development".

Following the world trend, Vietnam applied a low-cost airline (LCA) model in the Vietnam market since 2005. Since joining the low-cost airlines in Vietnam, LCA has brought more seat capacities and more opportunities for passengers who can't afford the full-service ticket. It also has a positive effect on Vietnam's tourism market during the economic crisis by offering more low-fare tickets for some tourism destinations. However, both of Vietnam's LCA presented a bad picture of a profitable business. Competition on prices made the situation worse together with fare cap control from the Government, high fuel prices leading to losses and more losses.

Service quality is one of the key factors leading to success in the airline industry. In this limited study, the author would measure Vietnam's LCA in the perception of Vietnam LCA passengers and finding out some recommendations for Vietnam LCA on improving their quality of service as well as to satisfy and retain passengers and that can improve profits to the airlines business. In order to identify the impact of service quality on customer loyalty in LCC in Vietnam, the authors would conduct a survey to examine the relationship between service quality and customer loyalty and the mediating roles of relationship quality in the context of the low-cost airlines in Vietnam.

\section{Literature review and hypotheses}

\subsection{Service quality}

Grönroos (1984) stated that a service is an activity or a series of activities of more or less intangible nature taking place in interactions between customers and service employees and/or systems of service providers, which are provided as solutions to customers' problems. An increase in air passengers has resulted in more demand in terms of the service quality offered by airline carriers (Oghojafor Ben et al., 2016). For the airline industry, a delivery of high service quality has become a marketing tactic to survive in such fiercely competitive pressures. Therefore, airline operators should create their own strategies to achieve the fulfillment of service expectation along with the service quality dimensions, the most considerable to air passengers to seize passenger satisfaction, trust, and loyalty (Akamavi et al., 2015; Forgas et al., 2010; Leong et al., 2015). Moreover, service quality is of great importance in aviation's competitive advantages by enhancing customer loyalty, coming to market share, creating profits (Ozment \& Morash, 1994). Hapsari (2017) stated that service quality is one of the most focused competitive variables and it is an emphasized driver of customer perceived value, airline image (Yang et al., 2012), and loyalty to the airlines (Leong et al., 2015). So, the following hypotheses are proposed:

$H_{1}$ : There is a positive influence of service quality on passenger loyalty.

$\mathrm{H}_{2}$ : There is a positive influence of service quality on passengers' perceived value.

$H_{3}$ : There is a positive influence of service quality on passenger satisfaction.

$H_{4}$ : There is a positive influence of service quality on passenger trust.

\subsection{Relationship quality}

Chonody et al. (2018) stated that "relationship quality has generally referred to an overall construct based on all previous experiences and impressions the customer has had with the service provider". The previous theoretical perspectives on relationships in client-vendor exchanges resulted in instruments developed to measure exchange relationship quality. The three most common variables used to contribute to the relationship quality measure are perceived value, trust, and satisfaction (Walsh et al., 2010). Satisfaction implies an evaluation regarding the products' acquisition and/or consumption experience (Giao et al., 2020). Thus, passengers' satisfaction is an evaluation based on their personal experiences with regard to their needs and expectations (Oliver, 2010). Some previous researches showed that passenger satisfaction could be influenced by service quality (Leong et al., 2015), perceived value (Yang et al., 2012). Besides, passenger trust is an important concept in the service organization. Mayer et al. (1995)defined trust as "the willingness...to be vulnerable to the action of another party based upon the expectation that the other will perform a particularly important action". It has been conceptualized as either a set of specific beliefs about an object of trust or a general belief about the object of trust. Trust has been widely discussed as a key factor for a successful business (Giao et al., 2020). Passenger trust could be derived by satisfaction (Akamavi et al., 2015). Moreover, Hellier 
et al. (2003) stated that the satisfaction level perceived by passengers after experiencing a service would influence their willingness to repurchase (loyalty) a product or service. Passenger loyalty was implied as a process of a person buying goods or services from the same suppliers. Moreover, it was explained as being loyal to a particular product or service when it came to a demand in the future. Many researchers found a positive association of satisfactions and trust on loyalty of passengers (e.g., Akamavi et al., 2015; Leong et al., 2015; Vuong et al., 2020). Based above discussions, they are suggested that (Fig 1):

$H_{5}$ : There is a positive influence of perceived value on passenger loyalty.

$H_{6}$ : There is a positive influence of passenger trust on passenger loyalty.

$H_{7}$ : There is a positive influence of passenger satisfaction on passenger loyalty.

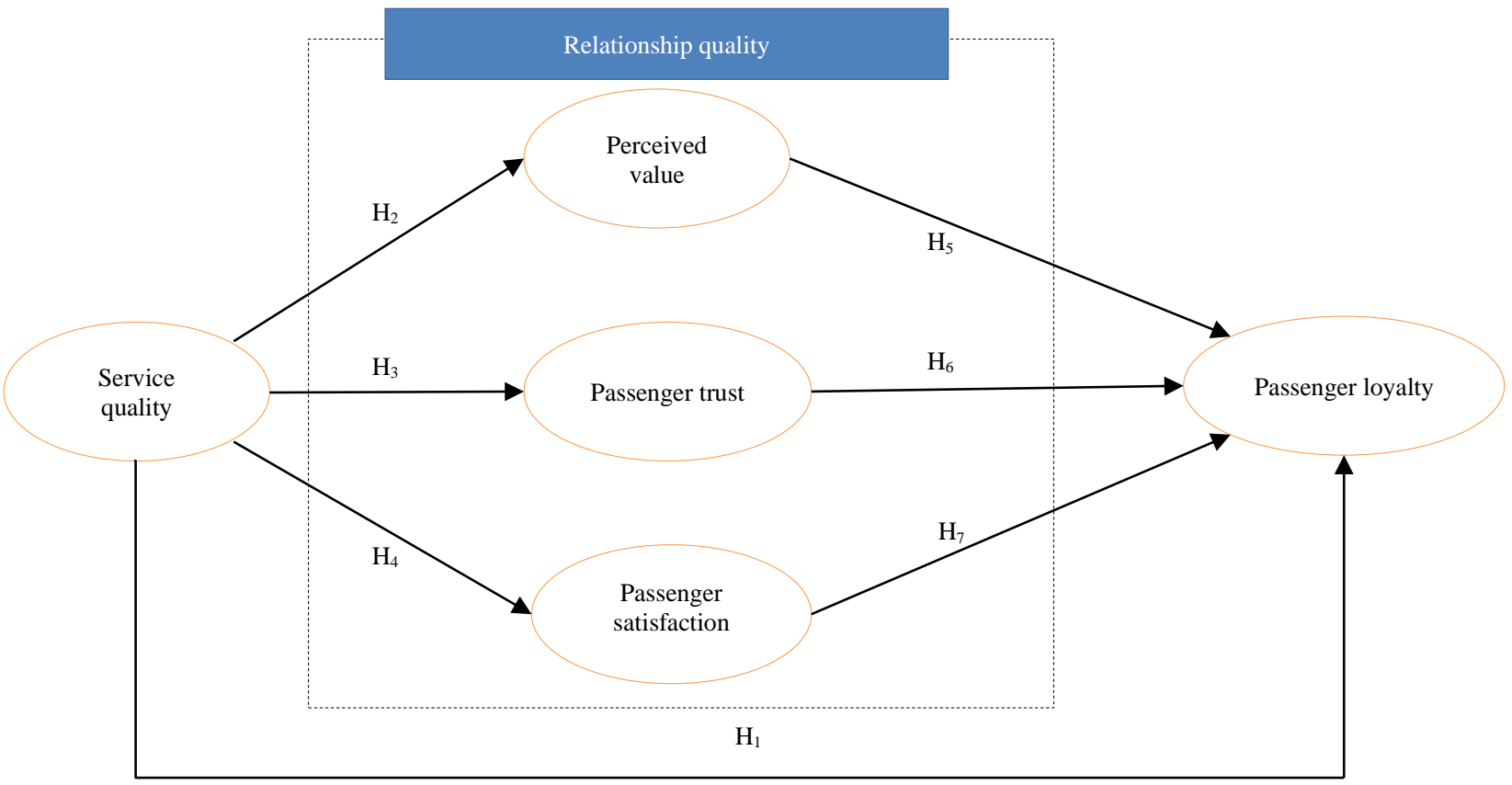

\section{Method}

Fig 1. Conceptual model.

\subsection{Sample}

Table 1. Distribution of the sample.

\begin{tabular}{|c|c|c|c|}
\hline & $\mathrm{N}=321$ & Frequency & Percent \\
\hline \multirow{2}{*}{ Gender } & Female & 151 & 47.0 \\
\hline & Male & 170 & 53.0 \\
\hline \multirow{2}{*}{ Marital status } & Married & 166 & 51.7 \\
\hline & Single & 155 & 48.3 \\
\hline \multirow{4}{*}{ Age } & $<26$ years old & 111 & 34.6 \\
\hline & 26-35 years old & 107 & 33.3 \\
\hline & $36-45$ years old & 60 & 18.7 \\
\hline & $>45$ years old & 43 & 13.4 \\
\hline \multirow{4}{*}{ Occupation } & Student & 51 & 15.9 \\
\hline & Self-employment & 131 & 40.8 \\
\hline & Professional & 114 & 35.5 \\
\hline & Retired & 25 & 7.8 \\
\hline \multirow{4}{*}{$\begin{array}{c}\text { Monthly income } \\
(1 \text { million VND } \approx 44 \text { USD) }\end{array}$} & Under 10 million VND & 117 & 36.4 \\
\hline & 10-20 million VND & 100 & 31.2 \\
\hline & 20-30 million VND & 90 & 28.0 \\
\hline & Above 30 million VND & 14 & 4.4 \\
\hline
\end{tabular}

The sample was selected using a nonprobability sampling with a technique-convenience sample. Target 
respondents of this survey were people who have used low-cost airline service in the domestic terminal in Tan Son Nhat airport, Ho Chi Minh City, Vietnam. The authors distributed directly to the passenger at Tan Son Nhat airport. In total, 343 responses were collected, but 22 questionnaires were eliminated because they were invalid (respondents just chose one option for all questions). Finally, there only 321 valid questionnaires were used for the data analysis process (Table 1).

\subsection{Measurement}

All constructs in the conceptual model were measured with multiple items, which were developed by previous researchers. All of the measurement scales used a five-point Likert scale including "Strongly disagree" $(=1)$, "Disagree" (=2), "Neutral" (=3), "Agree" (=4), and "Strongly agree" (=5) to explore the opinion of the respondents. Specifically, service quality was measured by 22 items of Leong et al. (2015). A sample item for this concept was "Employees of the airline that I choose are always willing to help me". Perceived value was measured by four items of Forgas et al. (2010). A sample item for this concept was "The aircraft seem modern and safe". Passenger satisfaction was measured by three items of Leong et al. (2015). A sample item for this concept was "I am satisfied with my decision to use this airline". Passenger trust was measured by four items of Akamavi et al. (2015). A sample item for this concept was "Most of what the LCA says about its products is true". Passenger loyalty was developed by four items of Akamavi et al. (2015). A sample item for e-loyalty was "I consider the LCA to be my first choice when flying".

\section{Data analysis and results}

The measurement model identifies the variables with their associated latent variables. Before performing PLS-SEM estimation, the validity and reliability of the multi-item measures were assessed (Vuong \& Suntrayuth, 2020). Following Giao and Vương (2019), who indicated that the composite reliability values should be 0.7 or greater to be considered reliable in a model, each variable was evaluated and charted to verify reliability. From Tables 2 presented, it is clearly stated that all the variables used in this research were reliable since they obtained the Composite Reliability and Cronbach's Alpha values more than 0.7. So, all values fall within the acceptable range to conclude good reliability. Moreover, convergent validity is the amount of variance when two or more items agree when measuring similar constructs and is calculated using the Average Variance Extracted (AVE). Convergent validity is said to be reliable when the AVE is above 0.50. Table 2 showed that AVE values were ranging between of 0.541 and 0.863 . Thus, all the items in the survey instrument are now considered convergent validity.

Table 2. Correlations of constructs, internal consistency, convergent, and discriminant validity.

\begin{tabular}{lccccccc}
\hline Construct & Cronbach's Alpha & $\begin{array}{c}\text { Average } \\
\text { Variance } \\
\text { Extracted } \\
\text { (AVE) }\end{array}$ & PL & PS & PT & PV & SQ \\
\hline PL & 0.878 & 0.804 & $(0.896)$ & 0.641 & 0.607 & 0.591 & 0.539 \\
PS & 0.921 & 0.863 & & $(0.929)$ & 0.508 & 0.621 & 0.528 \\
PT & 0.850 & 0.769 & & & $(0.877)$ & 0.568 & 0.572 \\
PV & 0.819 & 0.735 & & & & $(0.857)$ & 0.585 \\
SQ & 0.880 & 0.541 & & & & & $(0.736)$ \\
\hline
\end{tabular}

Notes: Square roots of average variance extracted (AVE) of latent variables are shown in the parentheses;

$\mathrm{PL}=$ Passenger loyalty, $\mathrm{PS}=$ Passenger satisfaction, $\mathrm{PT}=$ Passenger trust, $\mathrm{PV}=$ Perceived value, $\mathrm{SQ}=\mathrm{Service}$ quality

Besides, discriminant validity can be shown through the correlation matrix. The square root of a construct's AVE value should be greater than the squared correlation with any other construct "since a construct shares more variance with its associated indicators than it does with any other construct" (Vuong \& Giao, 2020). The table above (Tables 2) was the correlation matrices of the constructs with the diagonal values. Each construct square root of their AVE values was indeed greater than the squared correlation with any other construct. Therefore, discriminant validity has been established for the constructs. 


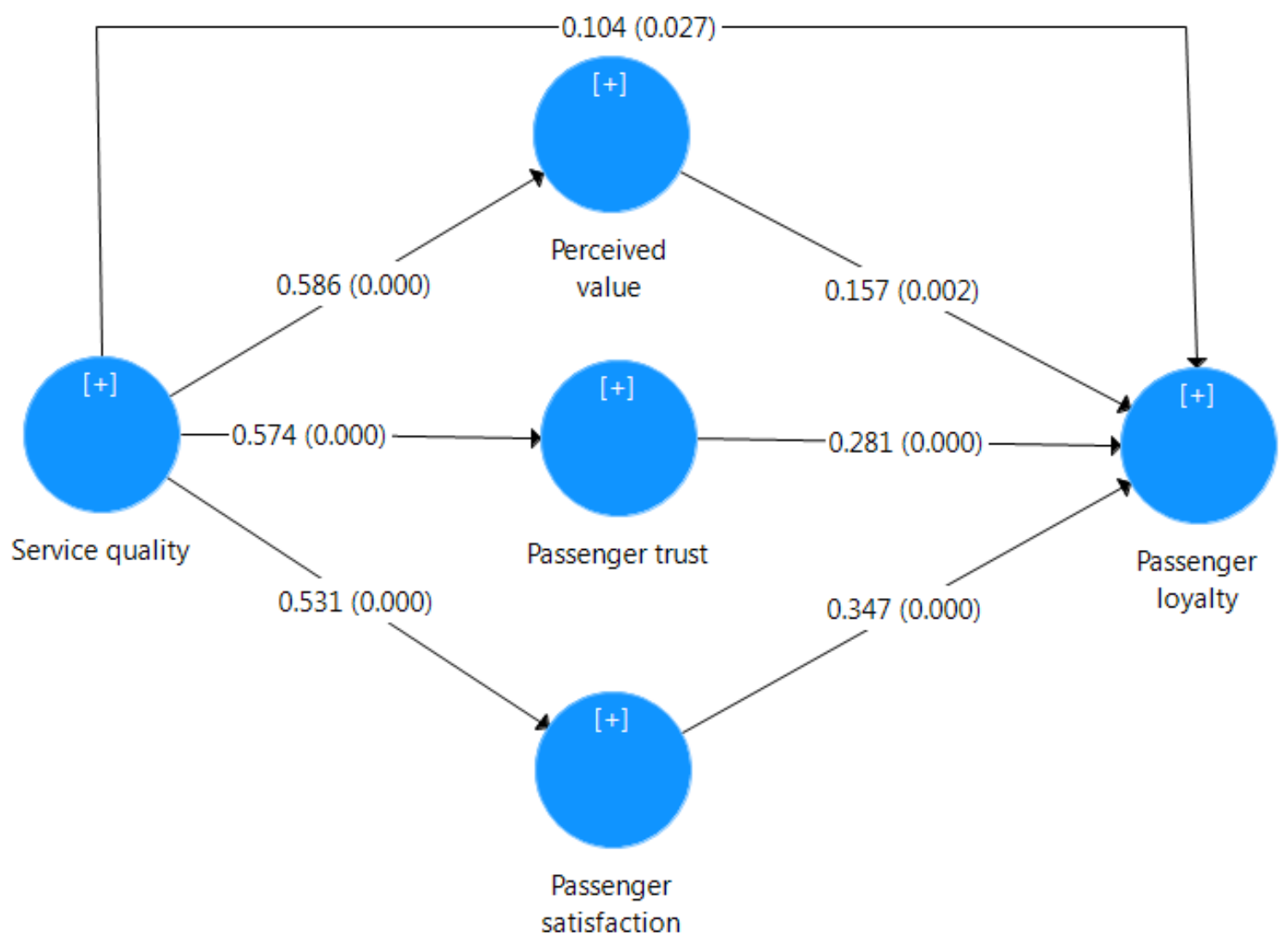

Fig 2. PLS-SEM model.

Hypothesis 1: the result showed that service quality had a positive and significant relationship with passenger loyalty (p-value $=0.027$ and beta coefficient $=0.104)$ (Table 3$)$. The results indicated that the higher service quality, the greater is the possibility that passengers will be loyal to the low-cost airline. Thus, hypothesis 1 was supported.

Table 3. Hypothesis testing results.

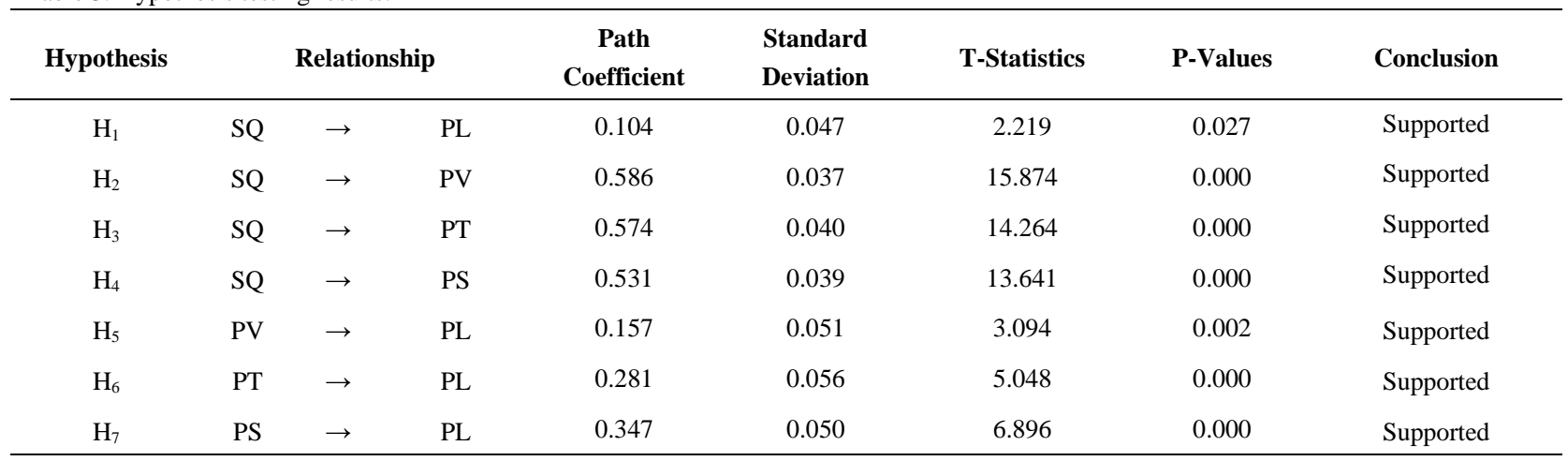

Notes: $\mathrm{PL}=$ Passenger loyalty, $\mathrm{PS}=$ Passenger satisfaction, $\mathrm{PT}=$ Passenger trust, $\mathrm{PV}=$ Perceived value, $\mathrm{SQ}=$ Service quality

Hypothesis 2: the result showed that service quality had a positive and significant relationship with perceived value ( $p$-value $=0.000$ and beta coefficient $=0.586)($ Fig 2$)$. The results indicated that the higher service quality, the greater is the possibility that passengers will have high perceived value about the low-cost airline. Thus, hypothesis 2 was supported.

Hypothesis 3: the result showed that service quality had a positive and significant relationship with passenger trust ( $\mathrm{p}$-value $=0.000$ and beta coefficient $=0.574$ ). The results indicated that the higher service quality, the greater is 
the possibility that passengers will have more trust about the low-cost airlines. Thus, hypothesis 3 was supported.

Hypothesis 4: the result showed that service quality had a positive and significant relationship with passenger satisfaction ( $p$-value $=0.000$ and beta coefficient $=0.254$ ). The results indicated that the higher service quality, the greater is the possibility that passengers will have more satisfaction with the low-cost airline. Thus, hypothesis 4 was supported.

Hypothesis 5: the result showed that perceived value had a positive and significant relationship with passenger loyalty ( $\mathrm{p}$-value $=0.002$ and beta coefficient $=0.157$ ). The results indicated that the higher perceived value, the greater is the possibility that passengers will be loyal to the low-cost airline. Thus, hypothesis 5 was supported.

Hypothesis 6: the result showed that passenger trust had a positive and significant relationship with passenger loyalty ( $p$-value $=0.000$ and beta coefficient $=0.281$ ). The results indicated that the higher passenger trust, the greater is the possibility that passengers will be loyal to the low-cost airline. Thus, hypothesis 6 was supported.

Hypothesis 7: the result showed that passenger satisfaction had a positive and significant relationship with passenger loyalty $(p$-value $=0.000$ and beta coefficient $=0.347$ ). The results indicated that the higher passenger satisfaction, the greater is the possibility that passengers will be loyal to the low-cost airline. Thus, hypothesis 7 was supported.

\section{Conclusion and implication}

The study investigated whether service quality has an impact on airline image, passengers' perceived value, trust, satisfaction, and loyalty in the context of LCA in Vietnam. Thus, the purpose of this study was to measure the relationship between service quality and passenger loyalty in the low-cost airline industry in Vietnam via the mediation roles of relationship quality (passengers' perceived value, trust, satisfaction).

The results showed that service quality had a significant impact on passenger loyalty. Besides, this study also indicated that service quality could improve passenger perceived value, trust, and satisfaction as well. The findings of this study were consistent with those of the previous researches in concluding that service quality was a significant determinant of passengers' perceived value, trust, satisfaction, and loyalty. Therefore, this study proposes some suggestions for the Vietnamese LCA managers such as follow:

Firstly, the questionnaire is based on the SERVQUAL scale applied in this research; it is an important contribution of this study. It developed through this study and is suitable for use by the Vietnamese LCA managers to create passenger loyalty.

Secondly, passengers indicated loyalty with the five dimensions of service quality examined in the study (tangibles, responsiveness, reliability, assurance, empathy), which implies that improvement intangible, empathy, responsiveness, assurance, reliability are the important issues that require attention from Vietnamese LCA to improve their business such as staff being trained to be friendly in dealing with customers and to realize their specific needs; the cost of service and level of service should always be consistent with the customers' expectations beside enhancing the services and accomplishing it on the agreed schedule, and finally, staff showing sincerity in handling services problems.

Airlines need to focus on ensuring that their tangible, physical evidence or service environment of their services is being taken care of as best as possible. They must be visually appealing and neat in appearance at all times. The layout and design of the aircrafts' cabins, employees' appearances, and even the air tickets should be developed in accordance with the expectations or requirements specified by the targeted market of a particular airline.

While airlines are focusing on improving their service quality, their standard of service during all service procedures, from booking tickets, check-in, in-flight, landing, and after services, still have a responsibility towards passengers. Airline managers should also conduct more service, knowledge, and skill training for all front-end staff with standard service programs for all airline front staff. Appraisal and compensation should be awarded to all good staff and KPI applied to all staff to guide them to standard service where LCA can achieve full passengers' satisfaction. Besides investing in their fleet and equipment, LCA should also build up trust from passengers on airlines facilities, while establishing a professional image and brand.

\section{Limitations and recommendations for future research}

There are some limitations of this study that should be noted in future researches. First, empirical research was conducted only in Viet Nam. Thus, data results are mainly reflected in customer behaviors in Vietnam. The author recommended replicating the study in different nations to get an international sample. Secondly, this study only focuses on service quality enhancing passenger loyalty, there could be other relevant factors and items that may be 
perceived as important by the passengers. In future researches, there should be a need to consider more factors impacting customers' loyalty.

\section{References}

Akamavi, R. K., Mohamed, E., Pellmann, K., \& Xu, Y. (2015). Key determinants of passenger loyalty in the low-cost airline business. Tourism Management, 46, 528-545.

Chonody, J. M., Gabb, J., Killian, M., \& Dunk-West, P. (2018). Measuring Relationship Quality in an International Study: Exploratory and Confirmatory Factor Validity. Research on Social Work Practice, 28(8), 920-930. doi: $10.1177 / 1049731516631120$

Forgas, S., Moliner, M. A., Sánchez, J., \& Palau, R. (2010). Antecedents of airline passenger loyalty: Low-cost versus traditional airlines. Journal of Air Transport Management, 16(4), 229-233.

Giao, H. N. K., \& Vương, B. N. (2019). Giáo Trình Cao Học Phuoong Pháp Nghiên Cúu Khoa Học Trong Kinh Doanh Cập Nhật SmartPLS. TP. Hồ Chí Minh, Việt Nam: Nhà Xuất Bản Tài Chính.

Giao, H. N. K., Vuong, B. N., \& Quan, T. N. (2020). The influence of website quality on consumer's e-loyalty through the mediating role of e-trust and e-satisfaction: An evidence from online shopping in Vietnam. Uncertain Supply Chain Management, 8. doi:10.5257/j.uscm.2019.11.004

Grönroos, C. (1984). A Service Quality Model and its Marketing Implications. European Journal of Marketing, 18(4), 36-44.

Hapsari, R. (2017). The impact of service quality, customer engagement and selected marketing constructs on airline passenger loyalty. International Journal of Quality and Service Sciences, 9(1), 21-40.

Hellier, P. K., Geursen, G. M., Carr, R. A., \& Rickard, J. A. (2003). Customer repurchase intention: A general structural equation model. European Journal of Marketing, 37(11), 1762-1800.

Leong, L.-Y., Hew, T.-S., Lee, V.-H., \& Ooi, K.-B. (2015). An SEM-artificial-neural-network analysis of the relationships between SERVPERF, customer satisfaction and loyalty among low-cost and full-service airline. Expert Systems with Applications, 42(19), 6620-6634.

Mayer, R. C., Davis, J. H., \& Schoorman, F. D. (1995). An Integrative Model of Organizational Trust. The Academy of Management Review, 20(3), 709-734.

Oghojafor Ben, A., Ladipo Patrick Kunle, A., \& Rahim Ajao, G. (2016). Airline Service Quality Dimensions and Customer Loyalty: Empirical Evidence from Air Passengers' in Lagos State. Czech Journal of Tourism, 5(2), $155-171$.

Oliver, R. L. (2010). Satisfaction: A Behavioral Perspective on the Consumer (2nd Ed.). New York: Routledge.

Ozment, J., \& Morash, E. A. (1994). The augmented service offering for perceived and actual service quality. Journal of the Academy of Marketing Science, 22(4), 352-363.

Vuong, B. N., \& Giao, H. N. K. (2020). The impact of perceived brand globalness on consumers' purchase intention and the moderating role of consumer ethnocentrism: An evidence from Vietnam. Journal of International Consumer Marketing, 32(1), 47-68. doi:https://doi.org/10.1080/08961530.2019.1619115

Vuong, B. N., Hieu, V. T., \& Trang, N. T. T. (2020). An empirical analysis of mobile banking adoption in Vietnam. Gestão e Sociedade, 14(37), 3365-3393. doi:https://doi.org/10.21171/ges.v14i37.3078

Vuong, B. N., \& Suntrayuth, S. (2020). The impact of human resource management practices on employee engagement and moderating role of gender and marital status: An evidence from the Vietnamese banking industry. Management Science Letters, 10(7), 1633-1648. doi:https://doi.org/10.5267/j.msl.2019.12.003

Walsh, G., Hennig-Thurau, T., Sassenberg, K., \& Bornemann, D. (2010). Does relationship quality matter in eservices? A comparison of online and offline retailing. Journal of Retailing and Consumer Services, 17(2), 130-142. doi:https://doi.org/10.1016/j.jretconser.2009.11.003

Yang, K.-C., Hsieh, T.-C., Li, H., \& Yang, C. (2012). Assessing how service quality, airline image and customer value affect the intentions of passengers regarding low cost carriers. Journal of Air Transport Management, 20, 52-53. 